\title{
From Civic Imperative to Bird's-Eye View: Renegotiating the Idioms of Education Governance during the Reconstruction Era
}

\section{Michael J. Steudeman}

The nineteenth-century debate about the role of the US Bureau of Education was marked by negotiations between the civic republican language of antebellum common school advocacy and a social scientific language of educational professionalism. To advance this argument, this essay traces how members of Congress defined, criticized, and delimited the Bureau's institutional role between 1865 and 1872. First, avoiding calls for direct federal intervention, the Bureau's initial congressional advocates defined the Bureau as a vehicle for indirect influence on the states through the use of data and statistics. Second, after the Bureau's founding, its legislative critics used rhetoric to chastise and question both the Bureau's comprehensive vision and power. Finally, beginning with Commissioner John Eaton's tenure in 1870, the Bureau's functions were narrowed. Due to Eaton's reimagining of the Commissioner role, further congressional critique, and failed efforts to expand Bureau authority, the Bureau eventually became a government-sanctioned purveyor of social scientific expertise-one with little direct authority to intervene in education.

Anxieties about the US Bureau of Education's fate weighed on Commissioner John Eaton Jr. as he delivered a keynote speech to the National Teachers' Association (NTA) at their Cleveland convention on August 17, 1870. The recently appointed Eaton faced the daunting task of defining his role to an audience of professors, principals, superintendents, and government officials —including President Ulysses S. Grant. ${ }^{1}$ Stepping into a maelstrom of contending views about federal education policy, Eaton chose a delicate metaphor. American education, he said, should be like a "flower clock," in

Michael J. Steudeman is Assistant Professor of Rhetoric in the Department of Communication Arts \& Sciences at Penn State University. He would like to thank Ethan Hutt, Trevor Parry-Giles, Shawn Parry-Giles, three anonymous reviewers, and the editors of HEQ for their feedback on previous drafts of this paper.

${ }^{1}$ John Eaton, Grant, Lincoln and the Freedmen: Reminiscences of the Civil War, in collaboration with Ethel Osgood Mason (New York: Longmans, Green, and Company, 1907), 248-60. 
which an arrangement of plants, naturally blooming at different times of day, would provide an accurate way to tell time. In turn, the Commissioner's role would be that of a botanist who plants idealistic seeds, waters the crops with guiding information, and closely watches as each state school system blooms in harmony with the others. Just as an overzealous gardener might disrupt the flowers' natural rhythms, he explained, a federal education leader's goals would be "defeated the moment harm is brought to the local vigor, wisdom, or results." ${ }^{2}$ If done properly, the speech implied, his work would be invisible.

In selecting such a gentle metaphor, Eaton recognized the precariousness of his new role. Since the Bureau's founding in 1867, the US Congress had clashed over its size, authority, and necessity. Its funding had been halved, then restored, then doubled. Its staff was cut to three, then expanded to ten. It was demoted from a bureau to an office, then elevated back to a bureau. It began as an independent agency, then moved to the Department of the Interior. ${ }^{3}$ As these debates unfolded, the Bureau's small staff struggled to fulfill its charge. Eaton's predecessor, school reformer Henry Barnard, resigned after a tumultuous term in which he published only one annual report in three years. ${ }^{4}$ The Bureau, the nation's first foray into federal education leadership, was a lightning rod of controversy. It is little wonder that Eaton sought to temper expectations and define his role as one of quiet influence and observation.

Debates over the Bureau formed a crucial part of a larger Reconstruction effort to engage the federal government in education. Building upon the passage of the Morrill Act in 1862, members of the postwar Congress advocated for the most ambitious expansion of federal involvement in education policy to that date. ${ }^{5}$ Starting in 1865 ,

${ }^{2}$ John Eaton, The Relation of the National Government to Public Education (Philadelphia: Educational Gazette Publishing Company, 1870), 9.

${ }^{3}$ For a detailed history of the Bureau of Education's development, see Donald R. Warren, To Enforce Education: A History of the Founding Years of the United States Office of Education (Detroit: Wayne State University Press, 1974). For the attempt at abolition, see Cong. Globe, 40th Cong., 2nd Sess., 3702-3703 (1868). For the Bureau's demotion to an Office, see Cong. Globe, 40th Cong., 3rd Sess., 1542-1543 (1869). For the restoration of its original funding and name, see Cong. Globe, 41st Cong., 2nd Sess., 1494 (1870).

${ }^{4}$ Edith Nye MacMullen, In the Cause of True Education: Henry Barnard and Nineteenth-Century School Reform (New Haven, CT: Yale University Press, 1991), $259-79$.

${ }^{5}$ On the history of congressional involvement in education during this period, see Michael David Cohen, Reconstructing the Campus: Higher Education and the American Civil War (Charlottesville: University of Virginia Press, 2012), 161-176; Goodwin Liu, "Education, Equality, and National Citizenship," Yale Law Journal 116, no. 2 (Nov. 2006), 330-410; Ward M. McAfee, "Reconstruction Revisited: The 
legislators fought to found the Bureau of Education, extend the Freedmen's Bureau's educational efforts, and require universal education in redrafted southern state constitutions. Even as Eaton detailed his botanical metaphor in 1870, members of the House of Representatives argued to dramatically expand his authority to intervene in states that failed to meet minimal education standards. In the course of arguments over these, and other, proposals, Congress clashed over federal obligations, authority, and influence in the educational affairs of locales and states. As a symbol of federal expansion and an instrument for enacting reformers' designs, the Bureau of Education was often at the center of these controversies.

Congressional debates about the Bureau between 1865 and 1872 captured the complex range of regional priorities, educational backgrounds, and partisan motivations that shaped the course of federal policy after the Civil War. Even among those who supported national education reforms in principle, wide disagreements existed about the extent and shape of the federal government's role. Bureau proponents such as Representative James A. Garfield embraced a nascent "science of government," believing that a small agency publishing statistical reports provided a way to induce states into embracing public schools. Bureau detractors, skeptical of the persuasive force of social scientific data, instead advocated for other forms of federal aid, influence, and intervention. Policymakers also disagreed about the power and position of the Commissioner of Education. Throughout Barnard's embattled tenure, he and members of Congress clashed over whether his role should resemble that of a state superintendent, an association president, a journal editor, or something else entirely. In Congress, established protocols of education research collided with the shifting expectations of postbellum government, leading to critiques of the scope, method, and content of Bureau reports.

Due to the diversity of congressional perspectives, the debates about the Bureau provide deep insight into the trajectory of postbellum education policy discussions. Nineteenth-century historians of educational history, the American state, and statistical sciences all track an interrelated set of changes between the 1850s and 1890s. A secular, professional regime of experts gained authority over the

Republican Education Crusade of the 1870s," Civil War History 42, no. 2 (June 1996), 133-53; Ward M. McAfee, Religion, Race, and Reconstruction: The Public School in the Politics of the 1870s (Albany: State University of New York Press, 1998); Alfred H. Kelly, "The Congressional Controversy over School Segregation, 1867-1875," American Historical Review 64 no. 3 (April 1959), 537-63; and Gordon C. Lee, The Struggle for Federal Aid, First Phase: A History of the Attempts to Obtain Federal Aid for the Common Schools, 1870-1890 (New York: Bureau of Publications, Teachers College, Columbia University, 1949). 
diffuse religious movements that spread education through the first half of the century. ${ }^{6}$ Government leaders began experimenting with ways to expand federal authority beyond that of the small, voluntary antebellum state. ${ }^{7}$ And policymakers adopted a rational, technocratic idiom of social science, slowly abandoning the civic republican language of the early nineteenth century. ${ }^{8}$ The heated debates of the Reconstruction Congress were at the nexus of these decades-long transformations in public life. The clash over a Bureau sheds light on how changes in domains of education, government, and social science became intertwined in the crucible of public debate. More importantly, the debates between Bureau supporters and detractors demonstrate how shifts in policy-making language did not happen as clear-cut turns from "old" to "new." Change happened through daily struggles in which the language of public life became blurred, redefined, and redirected. ${ }^{9}$

In this essay, I argue that the Bureau of Education debate marked a rhetorical re-negotiation of the idioms of educational governance. After contextualizing the transitional moment of Reconstruction, I trace how members of Congress defined, critiqued, and constricted the Bureau's institutional role. First, avoiding calls for direct federal intervention, the Bureau's initial congressional advocates defined the agency as a vehicle for showing states their shortcomings and shaming them into reform. Second, after the Bureau's founding, its legislative critics questioned both the Bureau's broad vision and efficacy. Finally, beginning with Eaton's tenure in 1870, the Bureau's functions were restricted. Influenced by Eaton's reimagining of the commissioner role, further congressional critique, and failed efforts to expand Bureau authority, the Bureau solidified as a government-sanctioned purveyor of social scientific expertise- one with little direct authority to intervene in education.

\footnotetext{
${ }^{6}$ David Tyack and Elisabeth Hansot, Managers of Virtue: Public School Leadership in America, 1820-1980 (New York: Basic Books, 1982).

${ }^{7}$ Williamjames Hull Hoffer, To Enlarge the Machinery of Government: Congressional Debates and the Growth of the American State, 1858-1891 (Baltimore, MD: Johns Hopkins University Press, 2007).

${ }^{8}$ James C. Scott, Seeing Like a State: How Certain Schemes to Improve the Human Condition Have Failed (New Haven, CT: Yale University Press, 1998); and Howard P. Segal, Technological Utopianism in American Culture (Chicago: University of Chicago Press, 1985), 98-128.

${ }^{9}$ This approach to rhetoric is described in James Jasinski, "A Constitutive Framework for Rhetorical Historiography: Toward an Understanding of the Discursive (Re)constitution of 'Constitution' in The Federalist Papers," in Doing Rhetorical History: Concepts and Cases, ed. Kathleen J. Turner (Tuscaloosa: University of Alabama Press, 1998), 72-92.
} 


\section{Postbellum Change and the Bureau Debate}

In various guises, American writers and policymakers had been debating the concept of centralized federal education leadership since the end of the eighteenth century. ${ }^{10}$ In the post-Revolutionary and antebellum United States, such proposals were often dead on arrival, too far removed from the realities of education's diffuse, local, associationdriven development. ${ }^{11}$ After over a half century of resistance, the tumult of the Civil War prompted fresh debates about federal involvement in public schools. The ideologies of Republican Party leaders, realities of wartime government, dilemmas of emancipation, and anxieties of postbellum reunion all contributed to the pursuit of bold policies and innovative arguments. Reformers' choice to advocate for a federal bureau was a product of three changes underway in postbellum educational governance and political thought. First, an increasingly organized generation of education reformers envisioned a bolder role for state and federal leadership. Second, national leaders had momentarily broken from the antebellum tradition of a small, associational state to expand the size and authority of the federal government. Finally, social scientists were founding associations and gathering supporters in a quest to forge a stronger supervisory state. Each of these changes represented a departure from the ideas of most prewar policymakers, and each encountered bitter resistance. The proposed bureau synthesized professional ambitions, centralizing impulses, and social scientific ideas, placing it at the center of postbellum controversies over the future of educational governance.

First, the 1860s accelerated a change in modes of educational leadership. As historians of education such as Carl Kaestle have noted, throughout the early to mid-nineteenth century, the character of educational reformers came out of differences in regional priorities. ${ }^{12}$ In the Northeast, common school advocates such as

${ }^{10}$ For a history of Bureau advocacy before 1866 , see Warren, To Enforce Education, 47-77. For example, as Congress debated how to appropriate a donation for what became the Smithsonian Institution in the 1830 s and 1840 s, a recurring theme focused on how best to promote education from the nation's capital. The debate also foregrounded earlier concerns with statistical observation and government involvement in science. Nina Burleigh, The Stranger \& the Statesman: James Smithson, John Quincy Adams, and the Making of America's Greatest Museum: The Smithsonian (New York: HarperCollins, 2003), 206-51.

${ }^{11}$ For examples of early proposals that did not gain traction, see Campbell Scribner, "False Start: The Failure of an Early 'Race to the Top,"' in The Founding Fathers, Education, and 'The Great Contest': The American Philosophical Society Prize of 1797, ed. Benjamin Justice (New York: Palgrave MacMillan, 2013), 69-83.

${ }^{12}$ Carl F. Kaestle, Pillars of the Republic: Common Schools and American Society, 17801860 (New York: Hill and Wang, 1983), 182-217. 
Horace Mann and Henry Barnard penned bold treatises on education to reinvigorate and centralize existing schools. In the South, reformers simply hoped to gain a foothold in a region resistant to taxpayerfunded schools. And in the sparsely populated West, Protestant clergy spread new schools in a millennialist "quest to create the Kingdom of God in America." ${ }^{13}$ Around the 1850s, educational leaders moved to make disparate state systems more cohesive. ${ }^{14}$ The 1855 launch of Barnard's American Journal of Education (AJE), for instance, stressed the need for a common language of educational professionalism and the creation of a federal agency to coordinate reform activity. ${ }^{15}$ Likewise, the founding of the NTA in 1857 and the National Association of School Superintendents (NASS) in 1865 widened efforts to shape policy at a national scale, including through a bureau. ${ }^{16}$

After the Civil War, education reformers began to work with members of Congress to realize their ambitions. According to religious historian Ward M. McAfee, Republican Party leaders who controlled the postbellum Congress embraced the public education as a "nationalist homogenizing symbol" and means to promote a unified, Protestant republic. ${ }^{17}$ Translating the ideas of education reformers into concrete policy, however, proved a vexing endeavor throughout Reconstruction. As Donald R. Warren asserts, arguments over the Bureau of Education were marred by disagreements amongst education leaders and members of Congress about the shape of federal reform. ${ }^{18}$ Partially in response to these challenges, over the next two decades the character of professional education leaders' arguments changed. Across efforts to lobby for federal aid in the 1870 s and 1880 s, for instance, Nancy Beadie traces professional associations'

${ }^{13}$ David Tyack, "The Kingdom of God and the Common School: Protestant Ministers and the Educational Awakening in the West," Harvard Educational Review 32, no.4 (Dec. 1966), 448-50; and Tyack and Hansot, Managers of Virtue, 30-31.

${ }^{14}$ Nancy Beadie, "The Limits of Standardization and the Importance of Constituencies: Historical Tensions in the Relationship Between State Authority and Local Control," in Balancing Local Control and State Responsibility for K-12 Education, ed. Neil D. Theobald and Betty Malen (Larchmont, NY: Eye on Education, 2000), 59.

${ }^{15}$ Henry Barnard, "Editorial Introduction," American Journal of Education 1 (August 1855), 1; and Henry Barnard, "Plan of Central Agency for the Advancement of Education in the United States," American Journal of Education 1 (August 1855), 134-36.

\footnotetext{
${ }^{16}$ Tyack and Hansot, Managers of Virtue, 46-51.

${ }^{17}$ McAfee, Religion, Race, and Reconstruction, 41.

${ }^{18}$ Warren, To Enforce Education, 22-24, 74-76, 122-150.
} 
growing reliance on statistical forms of persuasion. ${ }^{19}$ Historians David Tyack and Elisabeth Hansot write that by the century's end, "the rhetoric of reform shifted slowly from a revivalist Protestant-republican ideology to the language of science and business efficiency." 20 But at the time of the bureau debate in the mid-1860s, that change had only begun. ${ }^{21}$ Though zealous reformers attempted to seize the postwar opportunity, theirs was a moment of tension, still rife with dissonant regional prerogatives. The collision of those prerogatives in Congress illustrates the role of policy innovation and persuasive appeal in reshaping education policy.

Secondly, during the 1860s national leaders embraced arguments for expanded federal authority, creating space for a debate about an education agency. As political historian Brian Balogh recounts, the Civil War and Reconstruction marked a brief-albeit limited-departure from the nineteenth-century tradition of "hidden" federal governance through associational relationships. ${ }^{22}$ Responding to the demands of war and emancipation, the Republican Party embarked on a significant expansion of federal power. ${ }^{23} \mathrm{With}$ "states' rights"touting southern leaders gone from the legislature, the moment was ripe for internal improvements as well. As radical Republican leader Thaddeus Stevens candidly mused, the Union finally had a reprieve from that "insolent dictation which we have cringed to for twenty years, forbidding the construction of any road that does not run along our southern border." 24 The fervor for federal growth proved to be fitful, regularly checked by moderate interests still invested in preserving state and federal separation. ${ }^{25}$ It was also short-lived; by the mid-1870s, zeal for state power was tempered by an economic depression, white resistance to black civil rights, and the waning of

${ }^{19}$ Beadie, "The Federal Role in Education and the Rise of Social Science Research," 21-24, 30-33.

${ }^{20}$ Tyack and Hansot, Managers of Virtue, 107.

${ }^{21}$ Tyack and Hansot, Managers of Virtue, 103.

${ }^{22}$ Brian Balogh, A Government Out of Sight: The Mystery of National Authority in Nineteenth-Century America (New York: Cambridge University Press, 2009), 285-92; and Gary Gerstle, Liberty and Coercion: The Paradox of American Government from the Founding to the Present (Princeton, NJ: Princeton University Press, 2015), 118-23.

${ }^{23}$ Leonard P. Curry, Blueprint for Modern America: Nonmilitary Legislation of the First Civil War Congress (Nashville, TN: Vanderbilt University Press, 1968), 7-9; and Richard Franklin Bensel, Yankee Leviathan: The Origins of Central State Authority in America, 1859-1877 (New York: Cambridge University Press, 1990).

${ }^{24}$ Cong. Globe, 37th Cong., 2nd Sess., 1950 (1862).

${ }^{25}$ Kurt T. Lash, The Fourteenth Amendment and the Privileges and Immunities of American Citizenship (New York: Cambridge University Press, 2014), 6. 
federal enforcement in the South. ${ }^{26}$ Nonetheless, the Reconstruction Congress left behind tomes of transcripts that offer a glimpse of experiments in government expansion. There, historian and lawyer Williamjames Hull Hoffer writes, readers can find a "punctuated evolution of ideas" that began the shift from the small antebellum government to the Progressive Era state. ${ }^{27}$ Hoffer regards the Bureau debate itself as an attempt to expand federal authority through policies of "sponsorship, supervision, and standardization." 28 As members of Congress translated their educational visions into these novel approaches to federal policy, they molded educational language in ways unfamiliar to their antebellum predecessors.

Finally, the bureau debate also formed part of a broader argument over social scientific policy-making. The civic republican language of antebellum politics generally had a heterogeneous quality that permitted diverse forms of demonstration and proof. ${ }^{29}$ In the wake of the civil war, many policy leaders initiated the use of a more rational, scientific discourse of politics. Adverse to direct assertions of power, many adopted what James C. Scott dubs a "synoptic" ideal of governance. ${ }^{30}$ Through statistics, they aimed to indirectly solve social problems by making them visible and comprehensible. ${ }^{31}$ The American Social Science Association (ASSA), founded just months after the end of the Civil War, emerged to bring together reformers and politicians who shared a faith in science-driven policy. ${ }^{32}$ Across all levels of government, a growing faith in social scientific investigation helped elevate voluntary agencies into explicit government oversight roles. ${ }^{33}$ Nonetheless, during the 1860s, these arguments for social science were still relatively novel and subject to skepticism. In Congress, many doubted the persuasive force of scientific reports as

${ }^{26}$ Eric Foner, Reconstruction: America's Unfinished Revolution, 1863-1877 (New York: Harper \& Row, 1988), 412-511; and Heather Cox Richardson, The Death of Reconstruction: Race, Labor, and Politics in the Post-Civil War North, 1865-1901 (Cambridge, MA: Harvard University Press, 2001).

${ }^{27}$ Hoffer, To Enlarge the Machinery of Government, xii.

${ }^{28}$ Hoffer, To Enlarge the Machinery of Government, xi, 89-103.

${ }^{29}$ Daniel T. Rodgers, Contested Truths: Keywords in American Politics Since Independence (Cambridge, MA: Harvard University Press, 1998), 144-45.

${ }^{30}$ Scott, Seeing Like a State, 2.

${ }^{31}$ Scott, Seeing Like a State, 11-19; 89-90.

${ }^{32}$ Beadie, "The Federal Role in Education and the Rise of Social Science Research," 19; and Thomas L. Haskell, The Emergence of Professional Social Science: The American Social Science Association and the Nineteenth-Century Crisis of Authority (Urbana: University of Illinois Press, 1977).

${ }^{33}$ William R. Brock, Investigation and Responsibility: Public Responsibility in the United States, 1865-1900 (New York: Cambridge University Press, 1984), 8-10, 91-93. 
a way to change policy. Reading how members of Congress critiqued and defended statistical arguments during this time helps to discern the tactical reasons educators and politicians adopted them.

The proposal for a bureau of education emerged at the confluence of these three transitions. As the Civil War drew to a close, national education leaders asserted that disparate regional developments between the North and South had caused the war. ${ }^{34}$ Allying themselves with radical Republicans in Congress, they vitalized Barnard's proposal for a bureau as a way to unify national education priorities and bring cohesion to state systems. At their boldest, bureau advocates embraced the idea of the federal government as an agent of social reform. Speaking to the NTA in August of 1865, Cleveland Superintendent of Schools Andrew Jackson Rickoff issued a call to action, declaring a bureau of education a federal priority on par with postwar enforcement of freed people's civil rights and military protection in the South. Evincing a faith in statistical governance, Rickoff urged that the agency be modeled upon the scientific model of the Bureau of Agriculture. The "special duty" of the bureau, he asserted, would be to help "reorganize the government of the Southern States" to make common schooling accessible to all citizens, black and white. ${ }^{35}$ If detractors thought such an agency would render "the general Government a missionary ... to interfere with the family and social arrangements of the people," he added derisively, "well, be it so."36

Rickoff's words may have roused the average NTA member, but would have little appeal in the Reconstruction Congress. Frustrating centralizers' ambitions, the diverse and uneven growth of American education found expression in the words of representatives and senators. Many legislators arrived with backgrounds in school leadership, drawing on their experiences to tout wildly different visions of school governance. For example, Senator Charles Sumner, who began his political career as a Boston School Committee candidate groomed by Horace Mann, echoed the famed reformer's lofty words about the necessity of education in a republican government. ${ }^{37}$ Conversely,

${ }^{34}$ See, for instance, James P. Wickersham, "Education as an Element in Reconstruction," in National Teachers' Association, Proceedings and Lectures of the Sixth Annual Meeting (Hartford, CT: Office of the American Journal of Education, 1865), 283-97.

${ }^{35}$ Andrew Jackson Rickoff, "A National Bureau of Education," in National Teachers' Association, Proceedings and Lectures of the Sixth Annual Meeting, 303.

${ }^{36}$ Rickoff, "A National Bureau of Education, 303."

${ }^{37}$ William J. Reese, Testing Wars in the Public Schools: A Forgotten History (Cambridge, MA: Harvard University Press, 2013), 57-68; and Charles Sumner, The National Security and The National Faith; Guarantees for the National Freedman and the National Creditor (Boston: Geo. C. Rand \& Avery, 1865). 
Representative John B. Storm was a former county superintendent who developed a strong commitment to localism while traveling between rural Pennsylvania schoolhouses. ${ }^{38}$ As debates raged over federal education policy, regional differences like these mattered, informing where legislators stood on matters of local control, statistical influence, and the urgency of federal intervention. When a proposal for a bureau of education found its way to the House of Representatives, contending voices - of North, South, and West; of urban and rural; of local and state-tempered bold exertions like Rickoff's, beginning a process of deliberation.

Indeed, the first attempt in Congress to promote a bureau of education captured the challenges of adapting Rickoff's bold language to a regionally diverse legislature. When Congress convened in December of 1865, the young Representative Ignatius Donnelly from Minnesota issued an aggressive resolution that echoed Rickoff's NTA address. ${ }^{39}$ In his formative years, Donnelly had attended Central High School in Philadelphia, known as the "School of the Republic" for its zealous, meritocratic pedagogy. ${ }^{40} \mathrm{He}$ did not hesitate to bring that zeal to the floor of the House of Representatives. Donnelly called for a bureau of education "to enforce education, without regard to race or color, upon the population of all such States as shall fall below a standard to be established by Congress." ${ }^{41}$ Even on the verge of radical Reconstruction, the House proved far less receptive to such an assertive proposal than the NTA. For a legislature used to sustaining education almost exclusively by offering land grants, the proposal was absurd. ${ }^{42}$ Few wanted to be on the record supporting a call, however nonbinding, to "enforce education" upon the states. It would take a far savvier argument to make a bureau of education palatable to Congress. Like Eaton's "flower clock" botanist, a more successful vision of a bureau aimed to exert its influence only from a distance.

\footnotetext{
${ }^{38}$ John Storm, "Monroe County," in Report of the Superintendent of Common Schools of the Commonwealth of Pennsylvania ... 1865 (Harrisburg, PA: Singerly \& Myers, 1866), $155-57$.

${ }^{39}$ Cong. Globe, 39th Cong., 1st Sess., 60 (1865).

${ }^{40}$ David F. Labaree, The Making of an American High School: The Credentials Market and the Central High School of Philadelphia, 1838-1939 (New Haven, CT: Yale University Press, 1988), 13, 26-28, 173-82; and Martin Ridge, Ignatius Donnelly: The Portrait of a Politician (Chicago: University of Chicago Press, 1962), 5.

${ }^{41}$ Cong. Globe, 39th Cong., 1st Sess., 60 (1865).

${ }^{42}$ Before the Civil War, most federal participation in education happened through indirect means, for instance, through land grants made in accordance with the Northwest Ordinance of 1787. Lawrence A. Cremin, American Education: The National Experience, 1783-1876 (New York: Harper and Row, 1980), 9-10.
} 


\section{Defining the Bureau: Showing and Shaming, 1866-1867}

Three months after Donnelly's overambitious bureau resolution, the National Association of School Superintendents descended on Washington, DC, for its annual convention. To an audience that included several congressmen, Ohio School Commissioner Emerson Edward White modified the aggressive appeals of Rickoff and Donnelly into one that deferred more to localist tradition. Rather than enforce education, his envisioned bureau would "induce each state to maintain an efficient school system [emphasis added]" by issuing government-sanctioned reports. ${ }^{43}$ After hearing the speech, Representative James Garfield invited White to the library at his home in February of 1866. Together, the two Ohioans drafted a bill for a "National Department of Education." ${ }^{4}$ Rather than direct enforcement, their proposal instead advanced the idea of instigating education reforms by showing and shaming. By assembling statistical reports, the proposed bureau would provide a broad view of each state's educational progress. The instantaneous force of numbers would take the place of direct federal coercion, embarrassing state legislators, superintendents, and citizens into embracing school reforms. A way to promise federal influence without federal control, the visceral force of statistics formed the linchpin of Garfield's proposal. The bill's passage hinged on advocates' ability to synthesize familiar paeans to education with the emerging discourse of social science. They had to establish that merely seeing scientific reports would convince policymakers to support and reform their schools.

In many ways, Garfield was well poised to make an argument bridging the disparate voices of the Reconstruction Congress. He grew up in the Western Reserve of Ohio, where robust support for schools had been encouraged by the Northwest Ordinance of 1787, the popularity of the millennialist Disciples of Christ, and the region's migratory roots in New England reform culture. ${ }^{45} \mathrm{~A}$ witness to the formation of common schools in a Protestant frontier culture, Garfield

\footnotetext{
${ }^{43}$ Emerson E. White, "National Bureau of Education," American Journal of Education 16, no. 42 (March 1866), 180.

${ }^{44}$ Hoffer, To Enlarge the Machinery of Government, 92.

${ }^{45}$ On the influence of the Northwest Ordinance on education, see Robert S. Hill, "Federalism, Republicanism, and the Northwest Ordinance," Publius: The Journal of Federalism 18, no. 4 (Oct. 1988), 41-52. On the democratic Protestantism promoted by the Disciples, see Nathan O. Hatch, The Democratization of American Christianity (New Haven, CT: Yale University Press, 1989), 68-81; Allan Peskin, Garfield (Kent, OH: Kent State University Press, 1978), 7. On the reputation of the Western Reserve-sometimes dubbed "New Connecticut"-see Reverend G. H. Wells, "An Unparalleled Spectacle," in The World's Eulogies on President Garfield, ed. J. B. McClure (Chicago: Rhodes \& McClure, 1881), 194.
} 
went on to serve as the president of the Western Reserve Eclectic Institute. There, he worked closely with established educational bureaucrats to standardize teacher training, encourage readership of the Obio Journal of Education, and promote more uniform policy across the state. ${ }^{46}$ After serving as a general in the Civil War, he entered politics, finding a home for his religious zeal among the reformers of the Republican Party. He also became enamored of treatises on political science. Declaring a revolution underway in the theory of government, he joined the ASSA and advocated its theories in Congress. ${ }^{47}$ Social science was, for Garfield, an extension of his Disciple conviction that God's word was revealed, without interpretation, in the word of God itself. As he put it in an 1870 speech to the ASSA, "We can control terrestrial forces only by obeying ... those great laws of social life revealed by statistics." 48 Together, Garfield's experiences in religion, education, and social science prepared him to advance a nuanced argument for his envisioned bureau.

Despite his skills in public argument, convincing Congress to treat education policy as a scientific endeavor proved more difficult than Garfield imagined. White and Garfield based the department's indirect, statistical style of influence on the US Department of Agriculture (USDA), which Congress had approved just four years earlier. ${ }^{49}$ The comparison seemed compelling, but there was an important difference between agriculture and education: in 1866, American policymakers were far more prepared to accept agriculture

\footnotetext{
${ }^{46}$ For accounts of Garfield's lecture on the "Theory and Practice of Teaching," endorsement of professional education journals, support from educational associations, and reputation as a "teacher at Institutes," see "Intelligence: Cuyahoga Co. Teachers' Institute," Obio Journal of Education 8, no. 6 (June 1859), 187-88; "Editorial," Obio Journal of Education 8, no. 9 (Sept. 1859), 286; and "Editorial," Obio Journal of Education 8, no. 11 (Nov. 1859), 349. Today, the Western Reserve Eclectic Institute is named Hiram College.

${ }^{47}$ On Garfield's connections to the ASSA, see Peskin, Garfield, 306. For a major source of Garfield's views on statistical governance, see George Cornewall Lewis, $A$ Treatise on the Methods of Observation and Reasoning in Politics, vol. 1 (London: John W. Parker and Son, 1852).

${ }^{48}$ As cited in John Clark Ridpath, The Life and Work ofJames A. Garfield: Twentieth President of the United States (Cincinnati, OH: Jones Brothers, 1881), 217-18.

${ }^{49}$ Allan Peskin, "The Short, Unhappy Life of the Federal Department of Education," Public Administration Review 33, no. 6 (Nov. 1973), 572-75; and Peskin, Garfield, 294. Given the parallel histories of education and agriculture, the link between the two agencies seemed particularly intuitive to reformers. Warren, To Enforce Education, 70-76; Cremin, American Education, 335-52; and Lee S. Duemer, "The Agricultural Origins of the Morrill Land Grant Act of 1862," American Educational History Journal 34, no. 1 (Spring 2007), 135-46.
} 
as a science. ${ }^{50}$ Beyond the decennial literacy statistics the Census had published since 1840, there was little outside NTA proceedings that suggested a systematized science of education. ${ }^{51}$ Compared to the rational reports of the USDA, Henry Barnard's AJE seemed arbitrarily organized, jumping between teachers' anecdotes, reports on education abroad, speeches praising education, and exercises in phonetics. ${ }^{52}$ Though national reformers were starting to assert a discourse of professionalism and statistical data-gathering, many local advocates were more concerned with asserting the fundamental need for schools. To that end, educational rhetoric still possessed a civic glow, an irreducibility that rendered it a powerful tool for acculturating children out of illiteracy, poverty, criminality, and immorality. ${ }^{53}$ Though this republican language was not inherently incompatible with social science, the unaccustomed in Congress found the convergence of the two idioms hard to accept. There was, in short, a dissonance between how bureau proponents described education and the rational language they used to promote it.

When the proposed Department of Education arrived on the floor of Congress, this dissonance manifested in the arguments of Garfield's allies. Donnelly, agitated that Garfield's bill pursued more modest ends than his rejected resolution, argued for the more expansive bill he originally hoped to support. ${ }^{54}$ Without providing for education, Congress would "permit ignorance to spread over the land ... eating away our civilization, degrading our people, impeding commerce, destroying manufactures, making brutes of the masses and

${ }^{50}$ The Patent Office had been gathering statistical data for seed distribution since the late $1830 \mathrm{~s}$. Throughout the $1850 \mathrm{~s}$, market pressures facilitated language of rational administration and efficiency. And by 1866, USDA reports followed the form of positivistic science, replete with temperature charts, measurement scales, and tables of crop outputs. Alan I. Marcus, Agricultural Science and the Quest for Legitimacy: Farmers, Agricultural Colleges, and Experiment Stations, 1870-1890 (Ames: Iowa State University Press, 1985), 12-13; T. Swann Harding, Two Blades of Grass: A History of Scientific Development in the U.S. Department of Agriculture (Norman: University of Oklahoma Press, 1947), 18-19; Warren, To Enforce Education, 70-76; William Cronon, Nature's Metropolis: Chicago and the Great West (New York: W. W. Norton, 1991), 97-147; Theodore M. Porter, Trust in Numbers: The Pursuit of Objectivity in Science and Public Life (Princeton, NJ: Princeton University Press, 1995), 48; and Isaac Newton, ed., Bi-Monthly Report of the Agricultural Department for November and December, 1864 (Washington, DC: Government Printing Office, 1864).

${ }^{51}$ MacMullen, In the Cause of True Education, 244.

${ }^{52}$ For a history of the evolution of educational journals, including Barnard's, see Sheldon Emmor Davis, Educational Periodicals During the Nineteenth Century (Washington, DC: Government Printing Office, 1919), 63-91.

${ }^{53}$ Henry J. Perkinson, The Imperfect Panacea: American Faith in Education, 4th ed. (Boston, MA: McGraw-Hill, 1995).

${ }^{54}$ Ridge, Ignatius Donnelly, 101. 
demagogues of the leaders." Anticipating allegations of hyperbole, Donnelly stressed: "It is no flourish of rhetoric to say that we hold the destiny of mankind in our hands." ${ }^{55}$ For all his fiery appeals to education's necessity, though, Donnelly was unclear about how, precisely, a small department with a commissioner and four clerks would alter "the destiny of mankind." He made allusions to the national ministries of education in France, Prussia, and Austria, but did not acknowledge that the consolidated authority of those nations' school leaders made sweeping educational reforms far easier to implement. ${ }^{56}$ Under American federalism, all Donnelly could promise was a persuasive magic, "a mouthpiece and rallying point" that would "throw a light upon" the value of education. ${ }^{57}$ From there, he insisted, common school resistance would be swept aside. "A glorious assemblage shall pour forward," he said, strengthening "the newspapers, the public libraries, the multiplying railroads, the improved machinery for agriculture, [and] the increased comforts for the home, with liberality, generosity, mercy, justice, and religion." 58

Opponents of the proposal responded to Donnelly by declaring the proposed department both impotent and audacious. Democratic Representative Andrew J. Rogers, a former schoolteacher from the rural farming community of Lafayette Township, New Jersey, heaped skepticism on Donnelly's speech. ${ }^{59}$ Comparing Donnelly's bold predictions to the text of Garfield's bill, he argued that the bureau proposal "does not seem so broad in its terms as the speech of the gentleman from Minnesota would indicate." 60 In Rogers's view, the bill would create an agency so small as to be pointless. An occasional report surely would not have the sweeping influence Donnelly described. ${ }^{61}$ Despite the feebleness of the proposed department, though, Rogers still saw it as evidence of New England elitism. Stoking localist resentments, he claimed the bureau, at best, would employ centralizing nabobs who, "with their sheep-skin rolls and high sounding degrees," disdained

${ }^{55}$ Cong. Globe, 39th Cong., 1st Sess., 2968 (1866).

${ }^{56}$ Cong. Globe, 39th Cong., 1st Sess., 2967 (1866).

${ }^{57}$ Cong. Globe, 39th Cong., 1st Sess., 2968 (1866).

${ }^{58}$ Cong. Globe, 39th Cong., 1st Sess., 2968 (1866).

${ }^{59}$ All biographical information on members of Congress, unless otherwise noted, comes from the Biographical Directory of the United States Congress, http://bioguide.congress.gov/biosearch/biosearch.asp.

${ }^{60}$ Cong. Globe, 39th Cong., 1st Sess., 2968 (1866).

61 "If this bureau is not to have extensive ramifications throughout the country," Rogers suggested, "then it is simply for the payment of eight or ten clerks to do nothing, fifty or twenty thousand dollars annually." Cong. Globe, 39th Cong., 1st Sess., 2970 (1866). 
average citizens as "groveling in low ignorance." ${ }^{2}$ At worst, the bill would form the basis for future federal interventions, a "warrant ... to control and regulate the educational system for the whole country." ${ }^{3}$ Even if the department itself had no real power, Rogers suggested, it reflected an aspiration to impose the Massachusetts common school movement's dogma on the rest of the country.

Three days later, Samuel W. Moulton of Illinois tried to correct the record to show that the department would be both influential and sufficient for reformers' goals. As a former schoolteacher in several southern states and an advocate in the Illinois legislature for a statewide school system, he drew upon a nuanced knowledge of educational bureaucracy. Using his state as an example, he tried to clarify the logic of social scientific administration. As of 1853, he explained, the Illinois system was "in chaos. We had really no educational system at all. ... Everything was in confusion." ${ }^{4}$ The problem, as in the United States more generally, was that "there was no common center; no one to advise, direct, and suggest." ${ }^{65}$ The introduction of a state superintendent position created a guiding light. A decade later, Moulton continued, "we have twelve thousand school districts established, with magnificent school-houses dotted all over the prairies, and every Monday morning when the clock strikes nine o'clock half a million of bright-eyed girls and boys are within the walls of the common schools of Illinois." ${ }^{66}$ In place of a complex mishmash emerged a uniform system in which life imitated the superintendent's charts and tables. ${ }^{67}$ Nationally, a Department of Education would work the same way-it would "shed light in the dark places by disseminating facts and statistics, vitalizing and influencing by persuasion rather than by authority." 68

Moulton's explanation still garnered confusion about how disseminating statistics would concretely shape school systems. Republican Frederick Pike of Maine, for instance, criticized the unclear and limited "machinery" of the proposal. The bill failed to specify whether the commissioner and his clerks would "collect new

${ }^{62}$ Cong. Globe, 39th Cong., 1st Sess., 2969 (1866).

${ }^{63}$ Cong. Globe, 39th Cong., 1st Sess., 2968 (1866).

${ }^{64}$ Cong. Globe, 39th Cong., 1st Sess., 3045 (1866).

${ }^{65}$ Cong. Globe, 39th Cong., 1st Sess., 3045 (1866).

${ }^{66}$ Cong. Globe, 39th Cong., 1st Sess., 3045 (1866).

${ }^{67}$ In Scott's terms, the impetus was for the "chaotic, disorderly, changing social reality" to become "something more closely resembling the administrative grid of [rational] observations." Scott, Seeing Like a State, 82.

${ }^{68}$ Cong. Globe, 39th Cong., 1st Sess., 3045 (1866). Illinois Senator Richard Yates similarly claimed that the Bureau's benefit was that people "may see at a glance" the status of education. Cong. Globe, 39th Cong., 1st Sess., 1844 (1866). 
facts" like the Census Bureau, "send out its agents to gather them up and embody them," or simply "take the returns of the different States and analyze them." 69 Sharing the same concern, Democrat Samuel J. Randall of Pennsylvania wondered whether the commissioner's reports would offer any new information beyond what state superintendents had already gathered. Otherwise, he warned, "all this bill could possibly do would be just to copy the State superintendent's report and put it on file." 70 More fundamentally, Randall challenged the whole billiard-ball logic behind the bill. The way Moulton described it, the department would be detached from the world of children and teachers, of culture and Union. It merely facilitated some experts exchanging information. The bill, Randall warned, "does not propose to teach a single child, white, black or colored, male or female, its a b c's." 71

Rising to close the House's debate, Garfield had to thread a difficult needle. He needed to show how an administrative head in Washington could shape how the "a b c's" were taught thousands of miles away. To this end, he focused on the present invisibility of education's status, and the power that sight could bring. He took it as a given that every state, even in the most ignorant reaches of the South, had advocates like Moulton-state legislators or professional reformers who wanted to spread education. Their challenge was that they did not possess all the available means of persuasion. "I have searched in vain for any complete or reliable facts showing the educational condition of the whole country." Census data on illiteracy was superficial, state reports were incomplete, and supervision of land grants was inconsistent. ${ }^{72}$ Intrepid state legislators lacked the basic raw material for a good argument. Garfield reminded Congress "through what a struggle every state has come up that has secured a good system of common schools." Even with the blessing of historic heroes like Benjamin Franklin, "so foreign was the idea of public schools to the habits of the people" that Pennsylvanians nearly dismantled their system. ${ }^{73}$ The department would ease reformers' task through irrefutable illuminations.

Core to Garfield's argument were the instantaneous feelings of pride and shame provoked by scientific comparison. When inhabitants of poorly educated states saw themselves contrasted against citizens of

${ }^{69}$ Cong. Globe, 39th Cong., 1st Sess., 3047 (1866).

${ }^{70}$ Cong. Globe, 39 th Cong., 1st Sess., 3048 (1866). For a similar argument in the Senate, see Cong. Globe, 39th Cong., 1st Sess., 1844 (1866).

${ }^{71}$ Cong. Globe, 39th Cong., 1st Sess., 3048 (1866).

${ }^{72}$ Cong. Globe, 39th Cong., 1st Sess., 3049 (1866).

${ }^{73}$ Cong. Globe, 39th Cong., 1st Sess., 3050 (1866). 
better-educated states such as Ohio or Massachusetts, their response would be visceral. "The very light" of the reports "would shame out of their delinquency all the delinquent States of this country." 74 The emphasis on shame was crucial to Garfield's appeal, his answer to the vexing question of how a report in a DC commissioner's hands would shape the practice of a frontier teacher. In the disciplinary practice of nineteenth-century education, shame was tacitly understood as a potent way to shape student conduct- - even as treatises from prominent educational writers warned against it. ${ }^{75}$ Translated to the realm of policy, the cultivation of shame explained how a department could shape national policy without directly engaging in it. The department would wield "that power, so effective in this country, the power of letting in light on subjects and holding them up to the verdict of public opinion." 76

In the contentious postwar Congress, Garfield's appeal to shame made more headway than the bold resolution Donnelly issued earlier in the session. In a vote taken right after Garfield's speech on June 8, 1866, the bill was rejected by a margin of 61 to $59 .{ }^{77}$ Unfazed, Garfield proposed the bill again on June 19. This time, thanks to some behindthe-scenes lobbying, the bill passed by a margin of 80 to $44 .^{78}$ After a brief debate along similar lines, the Senate passed the bill the following February. ${ }^{79}$ The Senate's arguments produced only one change in the legislation, downgrading the name of the agency from a "Department" to a "Bureau of Education." ${ }^{80}$ More symbolic than substantive, this change anticipated ongoing pressures over the importance, role, and powers of the agency. Many in Congress had grand ambitions for the agency; many were passionate it should not exist at all. Even more fundamentally, many in Congress had competing ideas of what a "scientific" education report should look like and how a federal education leader should behave. Appointed Commissioner of Education, Henry Barnard soon became acutely aware of these tensions as he struggled to adapt his experiences as an educational professional to the vexing demands of federal administration.

\footnotetext{
${ }^{74}$ Cong. Globe, 39th Cong., 1st Sess., 3050 (1866).

${ }^{75}$ Peter N. Stearns and Clio Stearns, "American Schools and the Uses of Shame: An Ambiguous History," History of Education 46, no. 1 (2017), 58-75.

${ }^{76}$ Cong. Globe, 39th Cong., 1st Sess., 3050 (1866).

${ }^{77}$ Cong. Globe, 39th Cong., 1st Sess., 3051 (1866).

${ }^{78}$ Cong. Globe, 39th Cong., 1st Sess., 3269-3270 (1866); and Warren, To Enforce Education, 89.

${ }^{79}$ Cong. Globe, 39th Cong., 1st Sess., 1842-1845, 1893, 1949 (1866).

${ }^{80}$ Cong. Globe, 39th Cong., 1st Sess., 1842-1843 (1866).
} 


\section{Disciplining the Bureau: The Vision of the "Glass Eye," 1868- 1870}

The pressures of Reconstruction-era politics were immediately imposed on the Bureau. Even before it became law, President Andrew Johnson considered vetoing the bill until he received assurances that it would merely expand on the work of the Census Bureau. ${ }^{81}$ After less than a year of operation, members of the House Committee on Appropriations attempted to quietly deny the Bureau's funding in February of $1868 .^{82}$ Incensed, Garfield implored that eliminating the agency would be like tearing down a valuable lighthouse in the name of austerity. "I am not one of those who seek to pluck out the eyes of the nation," he impugned. ${ }^{83}$ Echoing Garfield, Donnelly defended the Bureau as "an eye watching the condition of that whole country, in an educational point of view." ${ }^{84}$ But opponents remained doubtful of the Bureau's purported "vision." One of many fellow Republicans to challenge the Bureau, Theodore M. Pomeroy of New York, rejoined that the agency was "but a glass eye; it has no sight in it; it has no power; it cannot inspect the system of education anywhere in the United States." ${ }^{15}$ These visual metaphors revealed a lack of clarity about what the synoptic state should "see" in education and an underlying confusion about the role of social science in shaping federal policy. Over the three years of Barnard's tenure, this confusion resulted in attacks on the Bureau's supervisory ability, scope of research, and professional domain. This criticism of the new Bureau tempered the ambitions of congressional school reformers.

Building on critiques during the first Bureau debates, many in Congress still doubted that aggregating data about literacy rates, school funding, and student attendance would have any meaningful effect on educational access. Surprisingly, many of these skeptics were radical Republicans who otherwise aggressively endorsed federal intervention in many areas of policy, including education. For Garfield, the most shocking opposition came from Representative Thaddeus Stevens. Three decades earlier, as a state legislator, Stevens established a firm reputation as an advocate of public schools. ${ }^{86}$ In his 1866 speech supporting the Bureau, Garfield

\footnotetext{
${ }^{81}$ MacMullen, In the Cause of True Education, 259.

${ }^{82}$ Cong. Globe, 40th Cong., 2nd Sess., 1139 (1868).

${ }^{83}$ Cong. Globe, 40th Cong., 2nd Sess., 1141 (1868).

${ }^{84}$ Cong. Globe, 40th Cong., 2nd Sess., 3703 (1868).

${ }^{85}$ Cong. Globe, 40th Cong., 2nd Sess., 3703 (1868).

${ }^{86}$ Thaddeus Stevens, The Famous Speech of Hon. Thaddeus Stevens of Pennsylvania in Opposition to the Repeal of the Common School Law of 1834 (Philadelphia: Thaddeus Stevens Memorial Association, 1904), 6-7. On Stevens's subsequent support for public
} 
even lavished praise on the elder statesman's "earnest and brave eloquence," by which he "gave a noble system of common schools to Pennsylvania." ${ }^{87}$ Stevens was not flattered. Blindsiding Garfield, he voted against the Bureau and, during an 1868 debate, called to abolish it altogether. ${ }^{88}$ How did Garfield so miscalculate Stevens's position? Their differences were partly regional, partly generational. In 1835, Stevens was fighting for the principle of public schools against legislators who sought to maintain a stratified system of pauper and private schooling. By contrast, Garfield's university leadership began four years after the passage of Ohio's 1853 statewide law requiring local tax-funded common schools. ${ }^{89}$ Where Stevens had been an evangelist of public education's virtue, Garfield's priorities had been closer to the systemizing efforts of men like Emerson Edward White. For Stevens, common school advocacy did not mean centralizing authority through "the gathering up of these facts by a worn-out man," but demonstrating education's merits to a reluctant public. ${ }^{90}$ To that end, he sought to repeal the Bureau and use the funds to instead help build a model school system in Washington, DC.

Other radical Republican adversaries of the Bureau represented districts with competing educational priorities, maligning the Bureau as too far removed from material human need. John F. Farnsworth of Illinois, for instance, questioned how "a gentleman stuck up here in the third or fourth story of some building in Washington" could, through disseminating "learned statistics" to other men "who never were inside a school-house," somehow influence a student's learning. ${ }^{91}$ The Bureau's approach, he inveighed, privileged "a book for the learned" over resources for the needy. ${ }^{92}$ "If this was an appropriation to purchase school-books, spelling books, and primers, to be distributed among the poor for the country," he argued in one debate, "I would vote for it." Bureau from Farnsworth's critique, comparing it to the USDA and arguing that it would, indirectly, inspire changes to help the poor. Farnsworth balked. "You cannot send out education as the

education, see Christopher Shepard, "Making No Distinctions Between Rich and Poor: Thaddeus Stevens and Class Equality," Pennsylvania History: A Journal of MidAtlantic Studies 80, no. 1 (Jan. 2013), 37-50.

\footnotetext{
${ }^{87}$ Cong. Globe, 39th Cong., 1st Sess., 3050-3051 (1866).

${ }^{88}$ Cong. Globe, 40th Cong., 2nd Sess., 3704 (1868).

${ }^{89}$ Kaestle, Pillars of the Republic, 187.

${ }^{90}$ Cong. Globe, 40th Cong., 2nd Sess., 3704 (1868).

${ }^{91}$ Cong. Globe, 40th Cong., 3rd Sess., 1542 (1869).

${ }^{92}$ Cong. Globe, 40th Cong., 3rd Sess., 1542 (1869).

${ }^{93}$ Cong. Globe, 40th Cong., 3rd Sess., 1542 (1869).
} 
Commissioner of Agriculture does seeds, done up in parcels," he rejoined. ${ }^{94}$ Garfield, he decided, had "gone mad on the subject of statistics."95 Beyond just stoking anti-intellectual resentments, Farnsworth was speaking on behalf of a constituency with an acute need for concrete educational aid. He represented the Illinois district that was home to Chicago, a city in the midst of explosive population growth. ${ }^{96}$ Schools there had struggled to keep pace with rising demand; between 1865 and 1867 alone, the city acquired over $\$ 680,000$ in loans or state-issued bonds just for the purpose of erecting new schoolhouses. ${ }^{97}$ Against that backdrop, Farnsworth had reason to malign the Bureau's approach to reform as obtuse.

In their critiques of the Bureau, many members of Congress turned their derision toward the Commissioner of Education himself. One sign of the Commissioner's supposed supervisory limits was a recurring question: Where in the world was he? Members of Congress and Bureau clerks were routinely frustrated that Barnard spent more time in Hartford, Connecticut, than in Washington. ${ }^{98}$ Even when he was in the capital, he proved notoriously difficult to find. Garfield's bill had neglected to provide office space for the Commissioner, leading to the frequent relocation of his workspace. ${ }^{99}$ The absent administrator became the butt of jokes in Congress; in one debate, Republican Elihu B. Washburne of Illinois mocked Barnard for operating from a tiny office above a restaurant (although, he admitted, "it is very convenient" to work close to a restaurant). ${ }^{100}$ More seriously, Rhode Island Representative Thomas Jenckes recounted running into a southern school commissioner in a DC bookstore who, on a search for information about other states' public schools, was surprised to learn that the Bureau even existed. ${ }^{101}$ Missouri Republican John F. Benjamin put the matter most

\footnotetext{
${ }^{94}$ Cong. Globe, 40th Cong., 2nd Sess., 3705 (1868).
}

${ }^{95}$ Cong. Globe, 41 st Cong., 2nd Sess., 1491 (1870).

${ }^{96}$ The population of Chicago grew nearly 900 percent in twenty years: from 29,963 in 1850 , to 109,260 in 1860, to 298,977 in 1870. US Census Bureau, Seventh Census of the United States: 1850: Volume IV, Compendium, Part VI, Population of Cities, Towns, \& c. (Washington, DC: Robert Armstrong, Public Printer, 1853), 347; US Census Bureau, Eighth Census of the United States, 1860: Volume I, Population, Part II, Florida-Illinois (Washington, DC: Government Printing Office, 1864), 90; and US Census Bureau, Ninth Census of the United States: 1870: Volume I, Population (Washington, DC: Government Printing Office, 1872), 110.

${ }^{97}$ Shepherd Johnston, Historical Sketches of the Public School System of the City of Chicago, to the Close of the Year 1878-79 (Chicago: Clark \& Edwards, 1880), 39-41.

${ }^{98}$ MacMullen, In the Cause of True Education, 259-66.

${ }^{99}$ Peskin, Garfield, 296.

${ }^{100}$ Cong. Globe, 40th Cong., 2nd Sess., 1139 (1868).

${ }^{101}$ Cong. Globe, 40th Cong., 3rd Sess., 1542 (1869). 
bluntly: "There was not a gentleman upon this floor who could tell where the office was located, or what it had been doing, or what had been the result of its labors." ${ }^{102}$ Uncertainty of Barnard's whereabouts reflected apprehensions about the Bureau's capacity to encourage change. To feel shame requires a sense of being watched, an internalized if not an actual gaze. ${ }^{103}$ If the Commissioner could not be found, who would notice him watching?

The criticism of Barnard reflected a disparity between how educational professionals and members of Congress imagined the Bureau of Education's role. Barnard envisioned his position as an extension of work he already performed with the NTA and $A J E$ - albeit with better funds and the government's sanction of his expertise. He quickly found that Congress had different expectations. For instance, as a fixture of association conferences and editor of the AJE, Barnard did not fear professional educators would malign him for choosing to work in any particular location. Obviously, federal legislators held him to a different expectation. Likewise, Barnard envisioned maintaining the $A J E$ as a crucial part of his Bureau responsibilities, just as state superintendents of education had for years retained editorship of common school journals. ${ }^{104}$ Members of Congress treated his continued stewardship of a privately edited journal as an act of corruption, a misuse of his federal salary. Garfield even sent a cautionary letter to Barnard warning him that his work on the $A J E$ threatened continued funding for the Bureau. ${ }^{105}$ The taken-for-granted assumptions that Barnard had cultivated in his prior decades of educational leadership simply did not align with those of federal leaders unfamiliar with his professional language.

Above all, congressional critics disparaged the composition of Barnard's Annual Report, an unruly nine-hundred-page document. Compared to the statistical language Garfield and Moulton invoked, Barnard's report treated educational "research" as a far broader domain. He incorporated educators' memoirs, pages of architectural designs, copies of federal laws, lengthy histories of colleges, speeches by political leaders commemorating school openings, pictures of schoolhouse radiators, detailed analyses of Prussian schools, and dozens of other harder-to-classify pieces of information. Stoking cries of

${ }^{102}$ Cong. Globe, 40th Cong., 3rd Sess., 1542 (1869).

${ }^{103}$ On the dynamics of shame in education, see Margaret Werry and Róison O'Gorman, "Shamefaced: Performing Pedagogy, Outing Affect," Text and Performance Quarterly 27, no. 3 (July 2007), 213-30.

${ }^{104}$ Tyack and Hansot, Managers of Virtue, 50-51.

${ }^{105}$ MacMullen, In the Cause of True Education, 266-69; and Warren, To Enforce Education, 129-30. 
nepotism, he even included a copy of Garfield's congressional speech advocating the Bureau of Education. ${ }^{106}$ None of the content was unusual for educational research at the time; much was republished from the AJE. But members of Congress were baffled by what they were reading. Senator Thomas A. Hendricks of Indiana dubbed the report "a compilation and collection together of scraps ... a collection of floating matter." 107 He could not fathom how this "gathering together of old things" would provide more helpful information to teachers than the more up-to-date, synthetic annual report of Indiana's superintendent. ${ }^{108}$ Defending Barnard's report from Hendricks, James Dixon of Connecticut remarked that it was "the product, in fact, of a life spent in education." ${ }^{109}$ For the Bureau's opponents, though, that was precisely the problem. Nothing in Barnard's massive personal educational library was off-limits.

In May of 1870, shortly after Barnard resigned and John Eaton assumed the Commissioner role, members of Congress hashed out whether the Bureau should continue and, if so, how it should work. In the view of Republican Senators Orris S. Ferry of Connecticut and James B. Howell of Iowa, the Bureau had been a failed experiment in promoting change through social science. The Bureau possessed "not one iota of power" to collect its data, Ferry concluded. It could only be viable if it hired actual flesh-and-blood officials to travel the country and visit schools. ${ }^{110}$ Howell agreed, noting that the Bureau lacked the robust connection to voluntary associations that made the USDA a success among farmers. To fulfill the Bureau's lofty objectives, he argued, Congress would need to appropriate at least a million dollars - nearly seventy times the agency's budget - to develop a direct supervisory role in the states. ${ }^{111}$ The bottom line, Ferry and Howell both agreed, was that a meaningful Bureau of Education was too expensive to be worth it. Still seeing a place for the Bureau, Republican Philetus Sawyer of Wisconsin challenged his colleagues. Instead of the tomes Barnard had published, Sawyer harbored a belief that clear, concise, straightforward reports could still be produced cheaply and exert meaningful influence. They could, that is, "if

${ }^{106}$ Anticipating congressional criticism, Barnard's introduction tried to account for his difficulties synthesizing the disparate material. Report of the Commissioner of Education, with Circulars and Documents Accompanying the Same ... 1868 (Washington, DC: Government Printing Office, 1868), x-xi; and Warren, To Enforce Education, 113-14.

${ }^{107}$ Cong. Globe, 40th Cong., 3rd Sess., 1796 (1869).

${ }^{108}$ Cong. Globe, 40th Cong., 3rd Sess., 1795 (1869).

${ }^{109}$ Cong. Globe, 40th Cong., 3rd Sess., 1796 (1869).

${ }^{110}$ Cong. Globe, 41 st Cong., 2nd Sess., 3334 (1870).

${ }^{111}$ Cong. Globe, 41 st Cong., 2nd Sess., 3335 (1870). 
properly performed." ${ }^{112}$ Embedded in that caveat was a normative expectation upon Eaton-one he would choose to accommodate as he began his role as caretaker of the "flower clock."

\section{Delimiting the Bureau: Adopting a Bird's-Eye View, 1870-1872}

When John Eaton Jr. became Commissioner of Education, he found that his predecessor Barnard had left him with "rooms ... so crowded with books, pamphlets, and desks as to be wholly unfit for successful clerical work." ${ }^{13}$ His impression of the office reflected how Eaton envisioned his task: one of cleaning up, organizing, and systemizing the mess his predecessor had left behind. He arrived at Congress with a résumé well suited to the rational predilections of congressional leaders like Sawyer. He had organized the support camps for fleeing freed people during the Civil War, restructured the Freedmen's Bureau in the midst of budgetary challenges, and served as Superintendent of Public Instruction in Tennessee during a period of postwar tumult. ${ }^{114}$ Over the first three years of a term that lasted until 1886, he and Congress restricted the Bureau's focus and functions in ways that persisted through much of the twentieth century. During this time, Eaton revised the Commissioner role, Congress exerted pressure on its research, and legislative failures guaranteed its scope would remain unchanged. Ultimately, the change from Barnard to Eaton captured, in microcosm, larger changes underway in mid to late nineteenth century ideas of educational leadership and persuasion. By 1872, the Commissioner role was circumscribed to the indirect influence of published reports, the contents of which definitively strived for the statistical and objective.

Eaton's first priority was to escape the critiques regularly lobbed at his predecessor's hodgepodge education reports. His first report differed markedly from Barnard's in both form and content. It opened with a one-page table of contents, offered a point-by-point summary of its conclusions, and provided identically formatted comparisons of various state systems. ${ }^{115}$ Even with a large appendix full of miscellaneous topics, the report more closely resembled a USDA or Census Bureau report than anything Barnard had published.

${ }^{112}$ Cong. Globe, 41st Cong., 2nd Sess., 3356 (1870).

${ }^{113}$ Report of the Commissioner of Education Made to the Secretary of the Interior for the Year 1870 (Washington, DC: Government Printing Office, 1870), 5; MacMullen, In the Cause of True Education, 278; and John Eaton, Grant, Lincoln and the Freedmen, 258.

${ }^{114}$ Stephen J. Sniegoski, John Eaton, U.S. Commissioner of Education, 1870-1886 (Washington, DC: Office of Educational Research and Improvement, 1995).

${ }^{115}$ Report of the Commissioner of Education ... 1870, 1-80. 


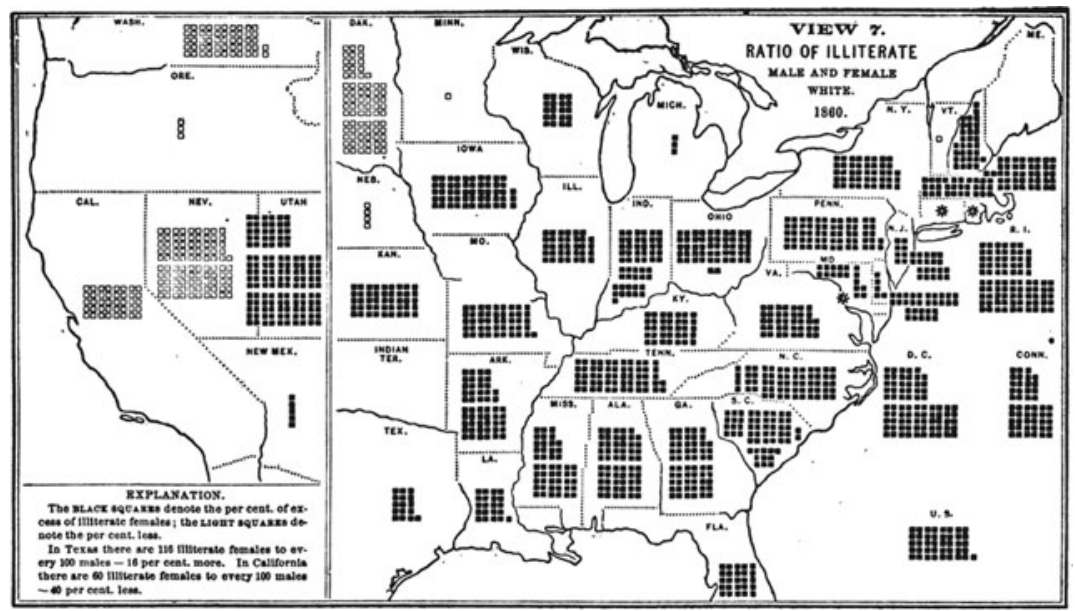

Figure 1. Ratio of Illiterate, Male and Female, White. 1860, (Report of the Commissioner of Education ... 1870), 492.

In perhaps the closest attempt to capture Garfield's synoptic idea of policy-making, Eaton incorporated a section of "Bird's Eye Views" of illiteracy rates in each state. Innovatively for American government reports at the time, these consolidations of Census Bureau data purported to provide "pictures of numbers" as they would appear "to the eye of a person passing over in a balloon" in each decade (Figure 1). ${ }^{116}$ Where Barnard had been hamstrung by a lack of respect for his professional autonomy, Eaton pivoted toward rational methods of quantification as "a strategy of impersonality" to deflect external critique. ${ }^{117}$ Eaton's implementation of rational structure, sweeping imagery, and statistical evidence into his reports, then, facilitated a shift from the character-centric ethos of antebellum reformers toward a more detached administrative logic. The benefit of a "Bird's Eye View" was that it did not draw attention to the expertise of the bird.

When Eaton did depart from the synoptic ideal, some members of Congress condemned him more vigorously than they ever had Barnard. The troubles began on February 11, 1871, when Democratic Senator Thomas Bayard objected to printing and distributing Eaton's

${ }^{116}$ Published in Report of the Commissioner of Education ... 1870, 482-502; and Susan Schulten, Mapping the Nation: History and Cartography in Nineteenth-Century America (Chicago: University of Chicago Press, 2012), 157-59.

${ }^{117}$ Porter, Trust in Numbers, xi. 
report without having a section about his state of Delaware "expunged." 118 Unable to obtain any official reports about the state, Eaton began the Delaware section of the report with a terse statement that "there appears to be an absence of any school supervision." 119 In place of official claims, he instead included quotations from anonymous educators criticizing Delaware schools. (According to one senator's paraphrase, Bayard was particularly offended by an observation that "boys did not stand in a straight line when they stood up to spell, and that they spat tobacco juice." ${ }^{20}$ ) While Bayard took no issue with the following page, which included the few statistics and legal details that Eaton could scrape together, he was incensed that Eaton would include "the mere opinions of self-styled educators, who have no official responsibility for their utterances, and not even personal responsibility, for their communication is anonymous." ${ }^{121}$ In the ensuing argument, senators worked out yet another vexing question of the postbellum transition in federal policy: On what grounds should Congress censor Bureau reports? For politicians committed to the original idea of the Bureau as a way to induce change in the states, Bayard's proposal appeared to set a dangerous precedent. As Republican Senator Frederick A. Sawyer of South Carolina explained, "If you begin by striking out one part, as soon as some other Senator reads the book and finds something that does not suit him he will want that stricken out too." 122

The dustup over Delaware illustrated both the limits of the Commissioner's authority and, curiously, that the agency's rhetoric of shame could work in precisely the way Garfield envisioned. Appealing to his responsibility as a father to teach his children to "speak the truth," Bayard persuaded the Senate to strike the page from Eaton's report as a caution against the future use of anonymous quotations. ${ }^{123}$ For others in Congress, though, Bayard's embarrassment on Delaware's behalf proved that the Bureau report was working as designed. If Delaware was frustrated by the lack of statistics, Sawyer mused, that was a spur for the state to develop much-needed state leadership. "Let the people of Delaware ... take care that in the next report they are fairly represented." 124 William M. Stewart of Nevada agreed: "Let them blush, not the Senate. ... When States appear to

\footnotetext{
${ }^{118}$ Cong. Globe, 41st Cong., 3rd Sess., 1131 (1871).

${ }^{119}$ Eaton, Report of the Commissioner of Education. . 1870, 103.

${ }^{120}$ Cong. Globe, 41st Cong., 3rd Sess., 1133 (1871).

${ }^{121}$ Cong. Globe, 41 st Cong., 3rd Sess., 1131 (1871).

${ }^{122}$ Cong. Globe, 41 st Cong., 3rd Sess., 1133 (1871).

${ }^{123}$ Cong. Globe, 41 st Cong., 3rd Sess., 1418 (1871); and Report of the Commissioner of Education ... 1870, 103.

${ }^{124}$ Cong. Globe, 41 st Cong., 3rd Sess., 1133 (1871).
} 
disadvantage a few times in this report, they will furnish the necessary information." 125 It does not matter here whether Bayard actually felt shame. What matters is that the Bureau report had altered the way members of Congress debated policy. Their rhetoric signaled a growing acceptance of Garfield's logic of supervisory reform.

Alongside attempts to explicitly censor Bureau reports, members of Congress continued to pressure the Commissioner to move away from the wide-ranging conceptions of educational research that had prevailed in antebellum reform movements. On February 20 and 21, 1871, Democratic Senator Eugene Casserly of California incisively picked apart Eaton's efforts in the lengthiest speech against the Bureau delivered in Congress to this point. ${ }^{126}$ The problem, in Casserly's view, was that Eaton followed Barnard in drawing too wide a scope for his inquiries. Instead of the two-hundred-page report the letter of the law would require, Eaton had instead published "a book of five hundred and seventy nine pages" that could well have been titled "De omnibus rebus et quibusdem aliis-'About everything in the world and several things besides." 127 Reading off the names of the report's miscellaneous sections, he questioned Eaton's choices of what to include. Why, he asked, did the report need lengthy sections on Ecuadorian schools, medical education, infant academies in Paris, or the nation's public parks? ${ }^{228}$ To the laughter of the galleries, Casserly mocked pages of commonsense aphorisms Eaton gathered from various school districts to capture conventional wisdom about teaching. ${ }^{129}$ In the end, arguments like Casserly's did not prevent Congress from sustaining the Bureau's funding, nor did they dissuade Eaton from publishing a second report that was twice as long and just as full of miscellany. ${ }^{130}$ Nonetheless, Casserly's arguments exhibited the type of pressure members of Congress would exert on the Bureau to hasten its conversion from the disorderly style of Barnard's AJE to a more austere standard of government reports.

As Eaton and his congressional critics clashed over the nature educational expertise, a pair of legislative failures solidified the limited authority of the Bureau. Beginning in 1870, George Frisbie Hoar of

${ }^{125}$ Cong. Globe, 41st Cong., 3rd Sess., 1134-1135 (1871).

${ }^{126}$ Sawyer estimated that the speech lasted between two and three hours, spread over the course of two days. Cong. Globe, 41st Cong., 3rd Sess., 1464 (1871).

${ }^{127}$ Cong. Globe, 41st Cong., 3rd Sess., 297 (1871).

${ }^{128}$ Cong. Globe, 41 st Cong., 3rd Sess., 297-299 (1871).

${ }^{129}$ Cong. Globe, 41 st Cong., 3rd Sess., 300 (1871).

${ }^{130}$ Cong. Globe, 41 st Cong., 2nd Sess., 3355-3357 (1870); Cong. Globe, 42nd Cong., 1st Sess., 666-671 (1871); and Report of the Commissioner of Education for the Year 1872 (Washington, DC: Government Printing Office, 1873). 
Massachusetts and his allies began pursuing a bill for a "National System of Education." Occupying the same seat in the House of Representatives that Horace Mann had sixteen years before, Hoar stressed that the collapse of upstart school systems in former Confederate states like Tennessee and Virginia demanded "the interference of the central power of the Republic."131 Blatantly rejecting Eaton's espoused vision of a gentle gardener tending a "flower clock," Hoar sought to empower Eaton to determine whether states met basic educational standards. If they failed, the Commissioner could then create schools, select superintendents, shape curriculum, and hire teachers within states deemed ineffective. ${ }^{132}$ Eaton supported the bill in principle; some even speculated that he wrote Tennessee Representative William F. Prosser's speech supporting the bill in $1870 .{ }^{133}$ Yet he also fretted that Congress would react strongly to the legislation's curricular provisions, writing to Hoar to suggest "relieving the National office of all responsibilities on the subject of text-books and leaving it to the state and district officers which your bill proposes to create." 134 Sure enough, the bill perished from the aggressive opposition of localist politicians. In 1871, Mississippi Representative Legrand Perce proposed a follow-up bill for a national common school fund derived from land grant sales. This bill also would have expanded the Commissioner's authority to evaluate states' management and deployment of federal dollars. ${ }^{135}$ It too was unsuccessful, passing the House but never reaching a vote in the Senate. ${ }^{136}$

The rejection of the Hoar and Perce bills set a trajectory for subsequent education policy, one that demarcated the Bureau's power but also helped perpetuate its use. An irony of the Perce bill debate was that localist arguers cited reports by the Bureau and similar agencies when attacking the idea of federal involvement in education. For instance, after an attempt by Hoar to critique the Kentucky school system, Democratic Representative Henry D. McHenry defended his state's honor with all the flair of a duelist. His rebuke cited education statistics to malign Massachusetts for its own failures to teach "children of poor and indigent parentage," who instead were often relegated to

${ }^{131}$ Cong. Globe, 41 st Cong., 3rd Sess., 808 (1871).

${ }^{132}$ Hoffer, To Enlarge the Machinery of Government, 108-15.

${ }^{133}$ Warren, To Enforce Education, 164; and McAfee, Religion, Race, and Reconstruction, $105-6$.

${ }^{134}$ John Eaton to George Frisbie Hoar, Feb. 2, 1871, document 143, carton 12, folder Feb. 1-15, 1871, George Frisbie Hoar Papers, Massachusetts Historical Society, Boston, MA.

${ }^{135}$ Cong. Globe, 42nd Cong., 2nd Sess., 535-536 (1872).

${ }^{136}$ George Frisbie Hoar, Autobiography of Seventy Years, vol. I (New York: Charles Scribner's Sons, 1903), 265; and Hoffer, To Enlarge the Machinery of Government, 116. 
factory labor. ${ }^{137}$ In short, the Bureau had become something tacitly understood as the background of congressional argument. By the start of 1871, even John F. Farnsworth, the Bureau's most persistent opponent in the House, admitted that it would be "impossible to get rid of, however useless it may be." 138 With the conclusion of the Perce bill debate, then, Eaton had little power to interfere in state or local affairs but a demonstrated ability to alter the course of education policy from a distance. He had, in a sense, become the botanist in his metaphor, quietly encouraging change from afar.

\section{The Bureau and the Trajectory of Nineteenth-Century Educational Governance}

The course Bureau proponents chose helps to explain the peculiar trajectory of federal school policy in the decades that followed Reconstruction. In her study of Progressive Era expansion in education, Tracy Steffes investigates how American schools became "so similar across the nation despite decentralized legal control and no significant federal role." ${ }^{139}$ Unlike nations with direct top-down orchestration of their schools, that uniformity had emerged in the United States from countless quotidian acts. As disparate district officials, state bureaucrats, association members, parents, and lawmakers searched for answers, they borrowed from their neighbors, learned from publications, listened to authorities, and adopted proven models. Among the experts consulted was the Bureau of Education, which Steffes credits with driving rural school reform in the early twentieth century. ${ }^{140}$ By goading states to change through seeing what others were doing, the Bureau worked exactly the way some of its most pragmatic advocates had hoped. From Garfield's initial proposal of showing and shaming to Eaton's internal reforms, the Bureau had been explicitly posited as an instrument of persuasion in a diffuse republic. Rather than regarding the centralizing efforts of the postbellum period as failures, then, it helps to contemplate the proposals that did persist and why.

Attending to the argumentative conflicts of the Reconstruction Congress helps reveal the qualities that made the Bureau both a limited agency and a persistent one. In the dissonant culture of the

${ }^{137}$ Cong. Globe, 42nd Cong., 2nd Sess., 789 (1872).

${ }^{138}$ Cong. Globe, 41 st Cong., 3rd Sess., 492 (1871).

${ }^{139}$ Tracy L. Steffes, School, Society, \& State: A New Education to Govern Modern America, 1890-1940 (Chicago: University of Chicago Press, 2012), 9.

${ }^{140}$ The Bureau "allowed each state to put itself into larger context," she explains, "which often provided incentive for individual states to reform." Steffes, School, Society, \& State, 80-81. 
Reconstruction-era Congress, the voices that proved most successful avoided language of direct federal intervention. Instead, they adapted their proposals to the forces that they understood as already, invisibly, driving national change. As Garfield explained in 1872, a "great American system of education" already existed, sustained by a combination of local, voluntary, and individual efforts. ${ }^{141}$ Federal assistance, he said, should only "be given through the channels of this, our American system." 142 Garfield's reasoning here was continuous with the argument he made for the Bureau six years earlier. To a legislature immersed in heated disputes about education reform, federal authority, and scientific influence, he had called for a small agency to gather data and publish persuasive reports. Seven years of subsequent debate honed the Bureau's functions in ways that addressed congressional opprobrium and withstood calls for abolishment. A product of institutional, political, and rhetorical adaptations, the shape of the Bureau thus reflected the diverse concerns that occupied Congress in the aftermath of the Civil War.

Over the course of the Bureau debate, congressional rhetoric revealed the acute political pressures that the Commissioner of Education faced. Barnard and Eaton occupied a position at the nexus of educational leadership and congressional prerogative. Members of Congress often dismissed or misunderstood the norms of school reformers at the Bureau, criticizing their research. Here too the Bureau debates provide insight into later Progressive Era developments. As Nancy Beadie argues, the consolidated, rational model of research adopted near the start of the twentieth century largely emerged in pursuit of, and in response to, failed efforts to enact a central federal policy during the decades after the Civil War. After this failure, she says, "The culture of expertise became a substitute for federal authority itself." 143 Returning to the Bureau case demonstrates the extent to which federal authority was, itself, deployed to condition that culture of expertise. By placing the professional domain of educational leadership under the aegis of congressional review, federal leadership sanctioned and delineated the language of expert authority. Conversely, the Bureau exerted its own influence on Congress, providing fodder for argument and gradually making the legislature more amenable to certain types of expertise. The reciprocal relationship between the Bureau and Congress thus played an early role in defining the very meaning of "scientific" research in education.

\footnotetext{
${ }^{141}$ Cong. Globe, 42nd Cong., 2nd Sess., 859-860 (1872).

${ }^{142}$ Cong. Globe, 42 nd Cong., 2nd Sess., 860 (1872).

${ }^{143}$ Beadie, "The Federal Role in Education and the Rise of Social Science Research," 33.
} 
Above all, the Bureau debate reveals the sheer diversity of educational perspectives that prevailed in the postbellum United States, offering a snapshot of words in transition. As members of Congress clashed over Eaton's first report, Senator Henry Wilson of Massachusetts wistfully recalled the intense resistance Horace Mann had felt at his efforts to centralize the school system of his home state. ${ }^{144}$ Like many of his fellow Bay Staters in Congress, Wilson viewed the march of progress in Massachusetts as a template for the transformation of the nation after the Civil War. But Mann's model, which Barnard strived to replicate, proved difficult to graft upon the contentions of the postbellum Congress. While Mann respected standardization and numbers, his reports were steeped in the dense style of Boston's genteel voice. ${ }^{145}$ Blurring expressions of civic republicanism, egalitarianism, commerce, and democracy, he posited education as a panacea for social ills, trekking back and forth across the state on horseback to spread a fervor for his conception of common schools. ${ }^{146}$ Further west, where there were no schools to make common, evangelists for education inspired communities to commit their meager resources to the promotion of literacy and intellect. Speaking in their own regional and religious words, they worried less about the uniformity of the system and more about how the next schoolhouse would be built.

The educational leaders and politicians devising the Bureau of Education were products of another time. Hailing from regions with uneven commitments to education, then forged in the turmoil of the Civil War, they groped toward languages of stability in a time of profound change. For Garfield and Eaton-the young general who founded the Bureau and the one who led it - this meant charting an uncertain course, a bridge between the civic republican rhetoric of the frontier and the centralizing designs of reformers like Mann. Seeking a language of educational policy-making that could make schooling more uniform across thousands of miles of fragmented polity, they strived to negotiate the tensions of their time. Reshaping discourses of educational leadership, federalism, and public policy, they helped begin-haltingly, gradually - a change in how Americans talked about education reform.

${ }^{144}$ Cong. Globe, 41st Cong., 3rd Sess., 1134 (1871).

${ }^{145}$ Dorothy C. Broaddus, Genteel Rhetoric: Writing High Culture in Nineteenth-Century Boston (Columbia: University of South Carolina Press, 1999); and Kathleen Edgerton Kendall, "Education as 'the Balance Wheel of Social Machinery': Horace Mann's Arguments and Proofs," Quarterly Journal of Speech 54, no. 1 (Feb. 1968), 13-21.

${ }^{146}$ Jonathan A. Messerli, Horace Mann: A Biography (New York: Alfred A. Knopf, 1972), 280-84. 